NBER WORKING PAPER SERIES

\title{
INTERNATIONAL CAPITAL MOBILITY \\ IN DEVELOPING COUNTRIES \\ VS. INDUSTRIAL COUNTRIES: \\ WHAT DO SAVING-INVESTMENT \\ CORRELATIONS TELL US?
}

\author{
Jeffrey A. Frankel \\ Michael Dooley \\ Donald Mathieson
}

Working Paper No. 2043

\section{NATIONAL BUREAU OF ECONOMIC RESEARCH 1050 Massachusetts Avenue \\ Cambridge, MA 02138 \\ October 1986}

This paper was begun when Frankel was a Visiting Scholar in the Research Department of the International Monetary Fund, in the Fall of 1985. The authors would like to thank Tom Walter for efficient research assistance. The research reported here is part of the NBER's research program in International Studies. Any opinions expressed are those of the authors and not those of the National Bureau of Economic Research. 
NBER Working Paper \#2043

October 1986

International Capital Mobility in

Developing Countries vs. Industrial Countries:

What do Saving-Investment Correlations Tel1 Us?

$\underline{\text { ABSTRACT }}$

The finding of Feldstein and Horioka (1980) that countries' investment rates are highly correlated with their national saving rates has by now been confirmed by many subsequent studies, even though their inference that international capital mobility must be low has not been as widely accepted. This paper exanines the statistical relationship between national saving and investrnent in a sample that includes not only 14 industrialized countries, but also 50 developing countries. The paper addresses some of the econometric critiques that have been aimed at the Feldstein-Horioka work. Contrary to what one would expect from consideration of capital mobility, the coefficient appears higher for industrialized countries than for developing countries, and higher after 1973 than before.

Our interpretation of the saving-investment evidence is that the hypothesis of a high degree of substitutability for claims on physical capital located in different countries is not supported by the data. International substitutability for financial capital may be high, but this is a separate condition (which is properly tested by looking directly at rates of return). High international substitutability for bonds would imply hizh international substitutability for physical capital if capital were perfectly substitutable for bonds within each country, but there is no reason for this to hold, any inore than there is for all goods to be perfect substitutes.

Jeffrey A. Frankel Department of Economics University of California Berkeley, CA 94720
Michael Dooley Research Department 9-302

IMF Washington, DC 20431
Donald Mathieson

Research Department 9-302

IMF

Washington, DC 20431 
Many subsequent studies have by now confirmed the finding of Feldstein and Horioka (1980) that countries' investment rates are highly correlated with their national saving rates. Nonetheless their inference that international capital mobility must be low has not been as widely accepted. This paper examines the statistical relationship between national saving and investment in a sample that includes not only 14 industrialized countries, but also 50 developing countries. Contrary to what one would expect from considerations of capital mobility, the coefficient appears higher for industrialized countries than for developing countries, and higher after 1973 than before. We find that these results survive econometric techniques designed to deal with some of the critiques that have been aimed at the Feldstein-Horioka work.

Our interpretation of the saving-investment evidence is that the hypothesis of a high degree of substitutability for claims on physical capital located in different countries is not supported. There is no contradiction between this conclusion and the hypothesis that some financial assets are perfect substitutes in the portfolios of international investors. This is a separate condition (which is properly tested by looking directly at rates of return). It could hold, and yet real interest parity fail, if goods are not perfect substitutes. 1/

The puzzle of higher saving-investment correlations for industrialized countries than for developing countries could then be explained by higher 
real exchange rate variability among the former. Alternatively, if direct international substitution between claims on physical capital--imperfect as it is--is considered more relevant than the roundabout route through financial capital and goods, then one could explain greater effects on investment in industrialized countries than in developing countries, even for the same degree of independent variability in rates of return, by assuming that investment in physical capital is more responsive to the domestic market rate of return in industrialized countries than in developing countries.

\section{Econometric Critiques of Savings-Investment Correlations}

Most of the econometric criticisms of Feldstein and Horioka can be subsumed in the general complaint that the righthand-side variable is correlated with the error term, that is, that national saving is endogenous. Though this problem is an ever-present danger in macroeconomics, it is particularly likely when the lefthand-side and righthandside variables, together with the current account, are linked by an identity •

Three conditions must hold before one could expect no relationship between investment and saving rates. Each is strong.

Condition 1: a country's investment rate depends onlv on a "representative" national real rate of return $r$ but not upon other variables that are correlated with domestic savings. For convenience we assume the relation to be linear: 


\section{(1) $I / Y=a-h r+\varepsilon$.}

The statistical support for the relationship between investment and the real interest rate has in fact always been disappointingly weak. We know

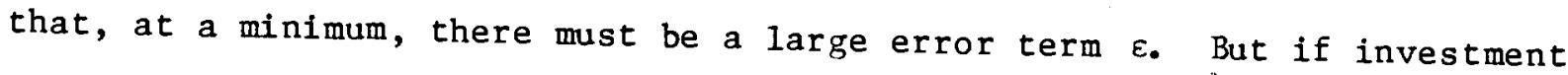
is to be uncorrelated with saving, it is crucial that this error term be purely random, that it be uncorrelated not only with the national rate of return, but also with national saving.

Condition 2: the domestic expected real rate of return relevant for investment and savings decisions must equal the foreign expected rate of return: $r=r^{*}$. If we think of the capital account as a function of the differential in returns,

\section{(2) $\mathrm{KA}=\mathrm{k}\left(\mathrm{r}-\mathrm{r}^{*}\right)$}

then the hypothesis is that $k$ is infinite. This is the only one of the three conditions that could properly be associated with the phrase "international capital mobility" as traditionally understood. (The other two conditions are econometric ones.) But, we will argue, financial capital mobility may not be sufficient to produce even this condition, if the condition is interpreted as the international equalization of expected real yields on physical capital.

Condition 3: the foreign expected rate of return relevant for saving and investment is determined exogenously. In other words, the domestic country is not large enough in world financial markets to affect the world interest rate. 
The statistic in question is $\operatorname{Cov}(I / Y, N S / Y)$, where $N S / Y$ is the ratio of national saving (private plus public) to income. I/ Using equation (1), we can decompose this covariance into three parts:

(2) $\operatorname{Cov}(I / Y, N S / Y)=\operatorname{Cov}(\varepsilon, N S / Y)-h \operatorname{Cov}(r-r *, N S / Y)-h \operatorname{Cov}\left(r^{*}, N S / Y\right)$

Condition 1 says the first term is zero, condition 2 the second term, and condition 3 the last term. If any of the three fails to hold, if any one of the links is broken, then there is no reason to expect the investment rate to be uncorrelated with the saving rate.

Each of the three conditions in fact of ten fails to hold. In order to gauge the empirical importance of these failures, this paper examines the statistical relationship between national saving and investment in a sample that includes not only 14 industrialized countries, but also 50 developing countries. 2/ The paper addresses some of the econometric critiques that have been aimed at the Feldstein-Horioka work. Contrary to what one would expect if physical capital was mobile across countries, the coefficient relating investment and national saving appears to be higher for industrialized countries than for developing countries, and higher after 1973 than before. Moreover, among developing countries there is a clear difference in the behavior of domestic saving and investment rates between countries that obtained external resources primarily through international capital markets and those that receive substantial official transfers. The saving and investment correlations for developing

1/ The regression coefficient is of course the covariance divided by the variance of $\mathrm{NS} / \mathrm{Y}$, and the correlation coefficient is the covariance divided by the standard deviation of each.

2/ Summers (1985a) and Fieleke (1982) also include developing countries in their samples. 
countries that rely on international capital markets are difficult to distinguish from industrial countries.

The remainder of this paper is divided into three sections. Section I first considers the econometric problems associated with examining the relationship between domestic saving and investment ratios. Section II considers empirical results for saving and investment relationships for different groups of developed and developing countries. Section III provides a rationale for the observed integration of markets for some financial instruments and the apparent isolation of national markets for real saving and investment.

II. Endogeneity of National Savings and Investment

One obvious version of the endogeneity problem that arises in time series studies is the strongly procyclical nature of both saving and investment, even when expressed as shares of GNP. If an exogenous boom causes both to rise, we do not want to attribute the correlation to low capital mobility. For this reasnn, Feldstein and Horioka restricted their analysis to cross-section data, as did most who followed in their footsteps. 1/ But even in time series studies, one can cyclically adjust the saving and investment data. $\underline{2}$ /

An alternative version of the problem that is relevant even for cross-section studies is the fact that the saving and investment rates both depend on the rate of growth of national income, as determined for example by population growth or productivity growth. This problem is

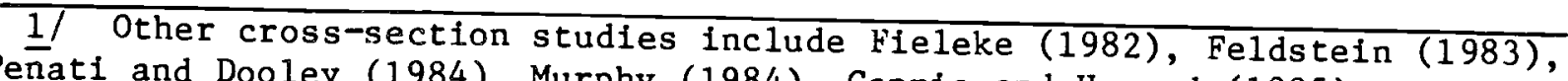
Peñati and Dooley (1984), Murphy (1984), Caprio and Howard (1985), and
Summers (1985a).

$2 /$ Sachs (1981) included a GNP gap variable in his regressions. Frankel (1985) tried two approaches: decade averages on a 10 year time sample of U.S. data, and cyclically-adjusted annual saving and investment rates on shorter postwar time samples. A third time-series study is obstfeld (1985).
} 
particularly relevant if the sample includes both industrialized countries and developing countries. One solution that has been applied is to add the rate of growth as a second explanatory variable. But the finding has been that holding the growth rate constant, like holding the business cycle constant, does not reduce the coefficient in the saving-investment regressions. $1 /$

The most popular version of the endogeneity critique is that governments react systematically to current account imbalances so as to offset them. For example, if the government reacts to a trade deficit induced by an increase in investment by cutting government expenditure or raising taxes, then national saving and investment will be correlated for reasons having nothing to do with capital mobility. 2/

It is important to realize how general the endogeneity argument is. Any economic variable, in addition to the cost of capital that influences the investment rate, will probably be correlated with the national saving rate. This is true not just of the level of income, population growth, and productivity growth, but also energy shocks, real wages, strikes, and so forth. $3 /$ If factors, other than the cost of capital, that determine

1/ Fry (1984) and Summers (1985a) both argue, in the context of 1/ Fry (1984) and Summers (1985a) both argue,
developing countries in particular, that the influence of the growth
rate on the other two variables explains the saving-investment correla-
tion. obstfeld (1985) makes the argument carefully, in the context of
OECD countries. But Summers ( $1985 a$, p. 22 ) added the rates of population
growth and GNP growth to his regressions and found no effect on the
saving coefficient.
2 The "policy reaction" argument has been made by Fieleke (1982),
Tobin ( 1983$)$, Westphal ( 1983$)$, Caprio and Howard ( 1984$)$ and Summers
(1985a, b). Summers calls it the "maintained external balance"
hypothesis.
$3 /$ Many of these factors would probably bias the correlation upward.
But some would go the opposite way, in the direction of a negative corre-
lation. If a country discovers oil, investment should go up but saving
should go down. Similarly, an investment tax credit should raise invest-
ment but lower the budget surplus and therefore national saving. 
investment happen to be uncorrelated with national saving, then there will be no econometric problem. (This is true even if government policy reacts systematically to current account imbalances.) But such a lack of correlation, with or without perfect capital mobility, is an absurdly strong condition. Since the difference between national savings and investment is identically equal to the current account it would imply that the factor in question has the identical effect on the current account as on investment.

If national saving depended on only the national rate of return and other factors thought to be random (uncorrelated not only with the rate of return but also with investment), we could invert the equation and regress national saving against investment. The hypothesis that foreign capital is in infinitely elastic supply at a given rate of return would imply a zero coefficient. This test would be equivalent (given the national saving identity) to regressing the current account against investment. The null hypothesis would in that case be a unit coefficient, implying that any exogenous changes in investment are fully financed by borrowing from abroad. This in fact is the equation run by Sachs $(1981,1983)$. But the idea that the rate of return is the only systematic determinant of both private and public saving has received even less support than the analogous assumption for investment. Clearly the right answer is that national saving, investment and the current account are all endogenous, and that some covariance among these variables is to be expected.

The question remains, however, as to why there is so little independent variation among these variables. Surely some of the factors that influence 
domestic savings do not have an equal and positive effect on investment. Yet it is shown in the next section that a positive covariance "near" to one is evident for very different country groups and over very different time periods. Moreover, the country group with the lowest correlation is also the group that relies the least on market-determined capital flows. It follows that factors which generate high correlations between national savings and investment in the presence of capital mobility must be remarkably similar both across country groups and over long time periods.

It seems important therefore to confront the "endogeneity" problem directly through an instrumental variables approach. Indeed, the original Feldstein and Horioka paper used instrumental variables. $1 /$ Two candidates for instruments for national savings are military expenditure and the dependency ratio (the population less than 15 years or 65 years or over in age, divided by the working age population in between). The former is most immediately a determinant of the government budget deficit (government dissavings) and the latter of private saving. It is possible to think of ways that either could be endogenous; it is conceivable that military expenditure could be cut back in response to trade deficits $2 /$ and that the age composition of the population could respond to the growth rate. But these two variables seem to meet the criteria for 1/ Their four instrumental variables were the ratio of retirees over the age of 65 to the population aged 20-65, the ratio of younger dependents to the working age population, the labor force participation rate of older men, and the benefit/earning "replacement ratio" under social security. $2 /$ Total government expenditure may not be a good enough instrument, as Summers (1985a) found, because under the policy-reaction argument it is endogenous. 
instruments better than most instrumental variables in macroeconomics. Regressions based on them are reported in the next Section.

\section{Results for the Relationship Between Investment} and National Saving

In this section, we examine the relationship between national saving, defined to include both private and public sector saving, and investment for a sample composed of 14 industrial countries and 50 developing countries. 1/ Our first objective is to consider whether the empirical results obtained for industrial countries (e.g., Feldstein and Horioka (1980) and Penati and Dooley (1984)) also extend to the developing countries, and whether the developing countries can be treated as a homogenous group or differ according to the nature of the resource transfer they receive from foreign sources.

Table 1 summarizes some of the empirical results based on ordinary least squares regressions that have been obtained in past studies for the savings and investment relationships for the industrial countries. Three preliminary conclusions are evident in these results. First, industrial countries that had relatively high rates of gross fixed investment also had relatively high gross domestic savings rates. Second, examined over time, industrial countries that accumulated capital

1/ The countries included in the sample are listed in the data appendix. 
Table 1. Industrial Countries: Saving, Investment, and Current Account Balances I/

Number of

Industrial

Countries

Sample Period

Regression Equation

$\mathrm{R}^{2}$

1. 15

$(1960-74)$

$(I / Y)=0.035+0.88(S / Y) \quad 0.91$

$(1.94) *(12.6)$

2. 17

$(1975-79)$

$(I / Y)=0.046+0.86(S / Y)$

0.57

$(1.09)(4.78) *$

3. 14

$(1971-79)$

$(C A / Y)=\begin{aligned} & 0.039-0.20(I / Y) \\ & (1.49)(1.89) *\end{aligned}$

0.21

4. 14

$(1971-79)$

$\begin{array}{rl}(\mathrm{CA} / \mathrm{Y})= & 0.03-0.20(\mathrm{I} / \mathrm{Y})+ \\ (1.27)(1.9) * & 0.280 \mathrm{IL} 0.28\end{array}$

5. 19

$(1960-74)$

$(C A / Y)=-0.002-0.02(I / Y)$

0.01 $(-0.08)(-0.27)$

6. 15

$(1960-69)-(1970-74)$

$\Delta(I / Y)=\begin{aligned} & 0.002+0.72 \Delta(\mathrm{S} / \mathrm{Y}) \\ & (0.50)(4.50) *\end{aligned}$

0.52

7. 15

$(1968-73)-(1974-79)$

$\Delta(\mathrm{CA} / \mathrm{Y})=\cdots \frac{-0.64 \Delta(\mathrm{I} / \mathrm{Y})}{(-6.2) *}$

0.72

8. 17

$(1968-73)-(1974-80) \Delta(I / Y)=\ldots+\underset{(\ldots)}{1.04 \Delta(S / Y)(\ldots)}$

9. 19

$\begin{aligned}(1968-73)-(1974-79) \Delta(\mathrm{CA} / \mathrm{Y}) & =-0.018-0.55 \Delta(\mathrm{I} / \mathrm{Y}) \\ & (-4.53) *(-3.6) *\end{aligned}$

0.43

10. 19

$(1968-73)-(1974-80)$

$\begin{aligned} \Delta(\mathrm{CA} / \mathrm{Y}) & =-0.018-0.39 \Delta(\mathrm{I} / \mathrm{Y}) \\ & (-4.51) *(-2.48) *\end{aligned}$

0.27

11. 19

$(1968-73)-(1974-79)$

$\begin{aligned} \Delta(I / Y)= & -0.014+0.83 \Delta(\mathrm{S} / \mathrm{Y}) \\ & (1.95) *(3.58) *\end{aligned}$

0.44

12. 19

$(1968-73)-(1974-80)$

$$
\Delta(\mathrm{I} / \mathrm{Y})=\begin{aligned}
& 0.013+0.81 \Delta(\mathrm{S} / \mathrm{Y}) \quad 0.53 \\
& (2.15) *(4.36) *
\end{aligned}
$$

13. 19

(1949-59)

$(I / Y)=\frac{0.053+0.69(\mathrm{~S} / \mathrm{Y})}{(2.13) *(6.25) *}$

0.69

14. 19

(1949-59)

$\begin{aligned}(\mathrm{CA} / \mathrm{Y})= & 0.009-0.04(\mathrm{I} / \mathrm{Y}) \\ & (0.32)(-0.30)\end{aligned}$

0.005 
Table 1 (concluded). Industrial Countries: Saving, Investment, and Current Account Balances $1 /$

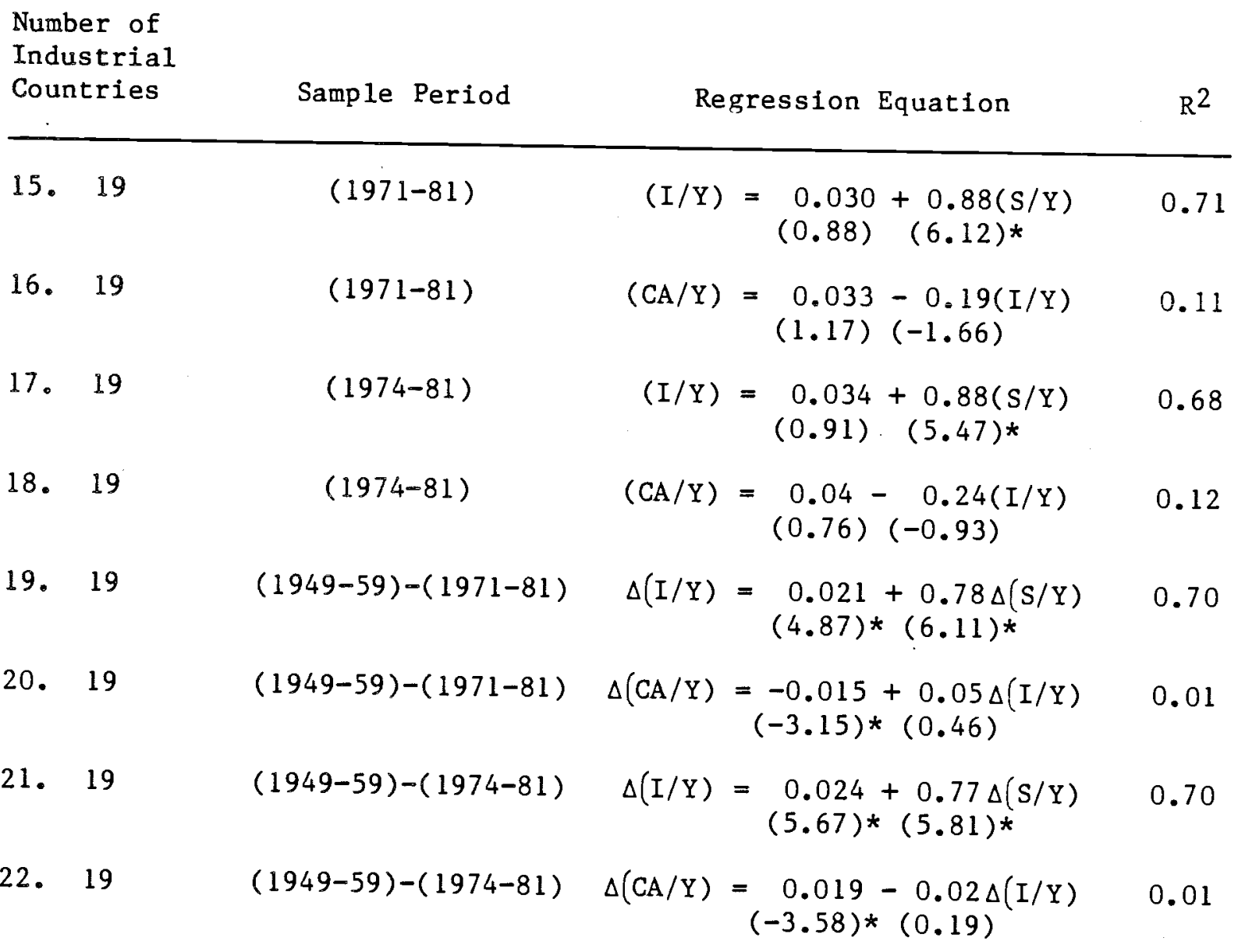

1/ Parentheses enclosing a period of years indicates the average value of the variables during that period. The delta $(\Delta)$ indicates the change from the average of the first period indicated in parentheses to the average of the second. Dots indicate that the statistic of the parameter is not reported by the authors. I denotes gross domestic fixed investment, $\mathrm{Y}$ gross national or domestic product, $\mathrm{CA}$ the current account balance including official transfers, $S$ gross national saving, and OIL the net imports of oil at constant prices. The t-statistics are shown in parentheses below the coefficients, and an asterisk (*) indicates that the coefficient is significant at the 5 percent level.

The sources for regressions $1-4$ and $6-8$ are as follows:

1, Feldstein and Horioka (1980), p. 321; 2, Feldstein (1983), p. 135; 3 and 4, Sachs (1983), p. 105; 6, Feldstein and Horioka (1980), p. 327; 7, Sachs (1981), p. 250; and 8, Feldstein (1983), p. 144. The remaining regressions are from Penati and Dooley (1984). 
more rapidly in the most recent periods also experienced increases in saving as a share of GNP. However, conflicting evidence was developed with regard to the relationship between investment ratios and current account ratios. For example, Sachs (1981, 1983) found a negative and significant slope coefficient in cross section regressions for either the levels or changes in current account balances and investment ratios. Such a relationship would be consistent with a high degree of capital mobility. In contrast, Feldstein and Horioka (1980) and Penati and Dooley (1984) did not find a significant negative coefficient; as a result, this evidence generally supports the view that changes in the propensity to save or to invest of residents of an industrial country were reflected in changes in that country's investment share or saving share.

To examine whether such relationships exist for developing as well as developed countries, our analysis first examines saving and investment behavior in these two groups of countries in two periods: 1960-73 and 1974-84. The first of these time periods represents the Bretton Woods era of fixed exchange rates. It might be expected that the degree of integration of markets for real savings and investment would be much higher in the second period, as the largest industrialized countries removed their capital controls, the OPEC surpluses were recycled, and the Eurocurrency markets experienced rapid growth.

Table 2 presents oLS regressions relating saving and investment ratios (for both the levels and changes in the ratios) for the groups of industrial countries, developing countries and all countries. For the 
Table 2. Ordinary Least Squares Regressions of the Investment Ratio (I/Y) Against

the National Saving Ratio (NS/Y) $1 /$

Country Group

(and number of countries)

Sample Period Regression Equation

Adjusted $\mathrm{R}^{2}$

Developing Countries

(50 observations)

\begin{tabular}{|c|c|c|c|c|}
\hline . $1960-73$ & $(I / Y)$ & $=\frac{.118 * t}{(.015)}$ & $\begin{array}{l}+.465 * *(\mathrm{NS} / \mathrm{Y}) \\
(.079)\end{array}$ & .40 \\
\hline $1974-84$ & $(I / Y)$ & $=\frac{.126 * t}{(.014)}$ & $\begin{array}{l}+.602 * *(\mathrm{NS} / \mathrm{Y}) \\
(.071)\end{array}$ & .59 \\
\hline $1960-73)-(1974-84)$ & $\Delta(I / Y)$ & $=\frac{.032 * t}{(.005)}$ & $\begin{array}{l}+.477 * * \Delta(\mathrm{NS} / \mathrm{Y}) \\
(.063)\end{array}$ & .54 \\
\hline
\end{tabular}

Industrial Countries

(14 observations)

$$
\begin{aligned}
& \text { 1960-73 } \\
& (I / Y)=\frac{.069 *}{(.026)}+\frac{.746 * *(\mathrm{NS} / \mathrm{Y})}{(.104)} \\
& 1974-84 \\
& (I / Y)=\frac{.063+.039)+(.173)}{(.036 *(N S / Y)} \\
& \begin{aligned}
(1960-73)-(1974-84) \Delta(\mathrm{I} / \mathrm{Y})= & -.001+\frac{1.040 * * \Delta(\mathrm{NS} / \mathrm{Y})}{(.005)}(.136)
\end{aligned}
\end{aligned}
$$

A1l Countries

(64 observations)

$$
\begin{aligned}
& \text { 1960-73 } \\
& (I / Y)=\frac{.118 * *-.049 \mathrm{DV}}{(.014)(.055)} \\
& +\underset{(.073)}{.465 * *(\mathrm{NS} / \mathrm{Y})}+\underset{(.223)}{.221 \mathrm{DV} .(\mathrm{NS} / \mathrm{Y})} .54 \\
& 1974-84 \\
& (I / Y)=\frac{.126 * *-.063 D V}{(.013)(.062)} \\
& +\underset{(.066)}{.602 * *(\mathrm{NS} / \mathrm{Y})}+\underset{(.275)}{.133 \mathrm{DV} .(\mathrm{NS} / \mathrm{Y})} \\
& \begin{aligned}
(1960-73)-(1974-84)= & .032 * *- \\
& (.005)(.034 * D V \\
& (.013)
\end{aligned} \\
& +\underset{(.057)}{.477 * * \Delta(\mathrm{NS} / \mathrm{Y})}+\underset{(.377)}{.563 \mathrm{DV} . \Delta(\mathrm{NS} / \mathrm{Y})} .65
\end{aligned}
$$

\footnotetext{
* Significant at 95 percent level.

* Significant at 99 percent level.

$1 /$ Standard errors are given in parentheses. $\Delta$ denotes the change in a given variable, and DV is a dummy variable which has the value of 1 (otherwise zero) when the country is an industrial country. See the Appendix for
} 
regressions relating the levels of the savings and investment ratios, all coefficients are highly significant statistically. Moreover, the coefficients are higher for the industrialized countries than for the developing countries, although we find that the difference in these coefficients is not statistically significant when the entire sample is pooled. This is the same finding as Summers (1985a): there is no sign of the greater ease that one would expect the more open industrialized countries to have in financing saving shortfalls. Nor is there any sign of the expected increase in capital mobility after 1973. The coefficient for all countries rises from 0.47 to 0.60 . This fallure of the coefficient to decline over time is the same result found by Feldstein (1983) and Penati and Dooley $(1984$, p. 9-10). $1 /$

These results are also supported by examining the relationship between the changes in the average saving and investment ratios over the periods 1960-73 and 1974-84. As indicated in Table 1, the slope coefficient relating the change in the average investment to income ratios to the change in the average savings to income ratio is positive and significant (at the 99 percent level) for both industrial and developing countries although the coefficient for the industrial countries is considerably higher.

To cope with the government policy reaction argument and the other forms of possible econometric endogeneity of national saving, we turn to

If And by Obstfeld (1985) and Frankel (1985a) for the case of the
United States.


instrumental variables regression. The two instrumental variables used in Table 3 are the ratio of military expenditure to GNP and the ratio of dependents to working-age population. (Two developing countries were dropped because data on their dependency ratio was unavailable; OLS regressions in the slightly reduced sample are reported in the top part of Table 2 for comparison.)

The results are striking. In the case of the developing countries, the coefficients lose all statistical significance. Indeed for the 1960-73 period, the sign is not even positive. This would appear to suggest that the high coefficients reported by many authors in oLs regressions are entirely attributable to econometric endogeneity problems, rather than to imperfect capital mobility, and that these problems are easily solved by the use of instrumental variables. The case of the industrialized countries is quite different: the coefficient actually increases somewhat. These results only heighten the puzzling conflict between the regressions and the presumption of higher capital mobility among the industrialized countries than among the developing countries.

A somewhat similar result emerges when changes in the average savings and investment ratios are employed. For the developing countries, the coefficients associated with the change in the savings ratio are approximately the same size and positive in both the OLS and instrumental variables equations, but the coefficient is not significantly different from zero in the instrumental variables case. However for the 
industrial countries, the comparable savings coefficient rises quite sharply in value but again becomes insignificant.

One possible explanation for these different results for industrial and developing countries is that the set of 50 developing countries is too diverse to treat as all having the same degree of capital mobility. In Tables 4 and 5, we focus on the distinction between a group of 21 market borrowers and 14 countries that depend primarily on official financing. (Fifteen countries are not classified by the Fund as either sort of borrower.) In the OLS regressions (Table 4) the positive and significant coefficients for the market borrowers, the official borrowers, and the combined set of market and official borrowers that was evident in Table 1 are still evident. Moreover, the coefficients are higher after 1973 than before, and they are also higher for the market borrowers than the official borrower.

The use of the instrumental variables technique (Table 5) has a much less important effect on the size and significance of the coefficients as it did when all the developed countries were included together, especially for the post-1973 period. For the market borrowers in particular, the point estimate of the coefficient now even exceeds unity, as it did with the industrialized countries in Table 2.

To sum up the results, the instrumental variables estimation does little to clear up the mysteries of the saving-investment correlations: why they are so high generally, and why they are even higher for the industrialized countries than for the developing countries, for the market borrowers than for the official borrowers, and after 1973 than before. 
Table 3. Regressions of I/Y Against NS/Y:

Developing Versus Industrial Countries 1/

Country Group

(and number of

countries )

Sample Period

Regression Equation

Adjusted $R^{2}$

Ordinary Least Squares

Developing Countries

( 48 observations)

$$
\begin{array}{rlrl}
1960-73(\mathrm{I} / \mathrm{Y})= & .120 * *+.455 * *(\mathrm{NS} / \mathrm{Y}) & .39 \\
1.015)(.082) & \\
1974-84 \quad(\mathrm{I} / \mathrm{Y})= & .122 * *+.610 * *(\mathrm{NS} / \mathrm{Y}) & .62 \\
& (.014)(.069) & \\
(1960-73)-(1974-84) \Delta(\mathrm{I} / \mathrm{Y})= & .030 * *+.474 * * \Delta(\mathrm{NS} / \mathrm{Y}) & .58 \\
& (.005)(.059)
\end{array}
$$

A11 Countries

(62 observations)

$$
\begin{aligned}
& 1960-73 \quad(\mathrm{I} / \mathrm{Y})=\frac{.120 * *-.051 \mathrm{DV}}{(.014)(.055)} \\
& +. .455 * *(N S / Y)+.291 D V .(N S / Y) \quad .53 \\
& \text { 1974-84 }(I / Y)=.122 * *-.059 . D V \\
& \text { (.013) (.061) } \\
& +.610 * *(\mathrm{NS} / \mathrm{Y})+.126 \mathrm{DV} .(\mathrm{NS} / \mathrm{Y}) \quad .61 \\
& (.065) \quad(.268) \\
& \begin{aligned}
&(1960-73)-(1974-84) \Delta(I / Y)= .030 * *- \\
&(.005) .031 * D V \\
&(.012)
\end{aligned} \\
& +.474 * *+.566 \mathrm{DV} . \Delta(\mathrm{NS} / \mathrm{Y}) \quad .68 \\
& \text { (.053) } \quad(.352)
\end{aligned}
$$

Instrument Variables Regressions:

Military Expenditure/GNP

and Dependency Ratio

Developing Countries

(48 observations)

$$
\begin{aligned}
& 1960-73 \quad(I / Y)= .350+.909(\mathrm{NS} / \mathrm{Y}) \\
&(.311)(1.84)
\end{aligned}
$$


Table 3 (concluded). Regressions of I/Y Against NS/Y: Developing Versus Industrial Countries 1/

Country Group (and number of countries)

Sample Period Regression Equation

Adjusted $\mathrm{R}^{2}$

$$
\begin{aligned}
& 1974-84(\mathrm{I} / \mathrm{Y})= \\
& \begin{array}{c}
.148+.465(\mathrm{NS} / \mathrm{Y}) \\
(.098)(.543)
\end{array} \\
&(1960-73)-(1974-84) \Delta(\mathrm{I} / \mathrm{Y})= .029 * *+.512 \Delta(\mathrm{NS} / \mathrm{Y}) \\
&(.006)(.324)
\end{aligned}
$$

Industrial Countries

(14 observations)

$$
\begin{aligned}
1960-73 \quad(\mathrm{I} / \mathrm{Y})=-.013+1.078 *(\mathrm{NS} / \mathrm{Y}) \\
(.069)(.277) \\
1974-84 \quad(\mathrm{I} / \mathrm{Y})=-.039+1.192 * *(\mathrm{NS} / \mathrm{Y}) \\
(.082)(.362) \\
(1960-73)-(1974-84) \Delta(\mathrm{I} / \mathrm{Y})=\frac{.023+2.096 \Delta(\mathrm{NS} / \mathrm{Y})}{(.048)(2.02)}
\end{aligned}
$$

A11 Countries

$$
\begin{aligned}
& 1960-73 \\
& (I / Y)=\underset{(.279) \quad(.350)}{.388)} \\
& -.909(\mathrm{NS} / \mathrm{Y})+1.987 \mathrm{DV} \cdot(\mathrm{NS} / \mathrm{Y}) \\
& (1.652) \quad(1.975) \\
& \text { 1974-84 } \\
& (I / Y)=\underset{(.093)}{.148}-(.1870) \\
& +\underset{(.517)}{.465(\mathrm{NS} / \mathrm{Y})}+\frac{.727 \mathrm{DV} \cdot(\mathrm{NS} / \mathrm{Y})}{(.694)} \\
& (1960-73)-(1974-84) \Delta(\mathrm{I} / \mathrm{Y})=\frac{.029 * *-}{(.006)}(.006 \mathrm{DV} \\
& +\underset{(.316)}{.512 \Delta(\mathrm{NS} / \mathrm{Y})+1.5840 V \cdot \Delta(\mathrm{NS} / \mathrm{Y})}
\end{aligned}
$$

* Significant at 95 percent level.

** Significant at 99 percent level.

1/ Standard errors are given in parentheses. $\Delta$ denotes the change in a given variable, and $D V$ is a dummy variable which has the value of 1 (otherwise zero) when the country is an industrial country. See the Appendix for definitions and sources of data. 
Table 4. Ordinary Least Squares Regressions of I/Y Against NS/Y:

Market Borrowers Versus Official Borrowers $1 /$

$$
\begin{aligned}
& \text { Country Group } \\
& \text { (and number of } \\
& \text { countries) } \\
& \text { Sample Period } \\
& \text { Regression Equation } \\
& \text { Adjusted } \\
& \mathrm{R}^{2} \\
& (I / Y)=\frac{.131 * *}{(.030)(.148)}+.445 * *(N S / Y) \\
& \text { 1974-84 } \\
& (\mathrm{I} / \mathrm{Y})=\underset{(.030)}{.049}+\frac{.878 * \pi(\mathrm{NS} / \mathrm{Y})}{(.120)} \\
& (1960-73)-(1974-84) \\
& \Delta(\mathrm{I} / \mathrm{Y})=\underset{(.005)}{.011 *}+\underset{(.073)}{.056 * \Delta(\mathrm{NS} / \mathrm{Y})} .80 \\
& \text { 1960-73 } \\
& (I / Y)=\frac{.128 * *}{(.027)(.366 * *(N S / Y)} \\
& 1974-84 \\
& (I / Y)=\frac{.120 * *-.678 * *(N S / Y)}{(.025)(.191)}
\end{aligned}
$$

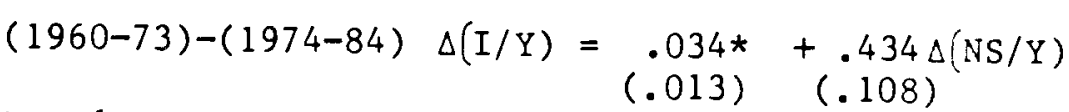

$$
\begin{aligned}
& \text { 1960-73 } \\
& (I / Y)=\frac{.131 * *-.003 D 0}{(.034)(.041)} \\
& +\frac{.445 *(\mathrm{NS} / \mathrm{Y})}{(.164)}-\frac{.079 \mathrm{DO} .(\mathrm{NS} / \mathrm{Y})}{(.203)} .33 \\
& 1974-84 \quad(I / Y)=\frac{.049}{(.028)}-\frac{.072 \mathrm{DO}}{(.040)} \\
& +\underset{(.112)}{.878 * *(\mathrm{NS} / \mathrm{Y})}-\underset{(.244)}{.200 \mathrm{DO} .(\mathrm{NS} / \mathrm{Y})} .71
\end{aligned}
$$

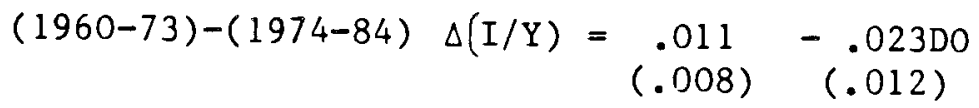

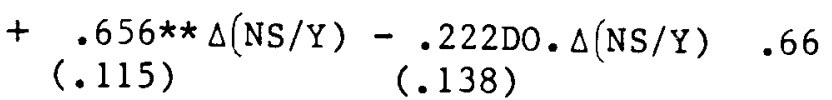

\footnotetext{
* Significant at 95 percent level.

** Significant at 99 percent level.

1/ Standard errors are given in parentheses. $\Delta$ denotes the change in a given variable, and Do is a dummy variable which takes on the value of 1 (otherwise zero) when the country is an official borrower. See the Appendix
} 
Table 5. Regressions of I/Y Against NS/Y:

Market Borrowers Versus Official Borrowers 1/

Country Group (and number of observations)

Sample Period Regression Equation

Adjusted

$\mathrm{R}^{2}$

Ordinary Least Squares

Official Borrowers

(13 observations)

$$
\begin{array}{rlrl}
1960-73 & (\mathrm{I} / \mathrm{Y})= & .133 * *+.350 *(\mathrm{NS} / \mathrm{Y}) & .30 \\
1.029)(.142) & \\
1974-84 & (\mathrm{I} / \mathrm{Y})=\begin{array}{ll}
.114 * *+.686 * *(\mathrm{NS} / \mathrm{Y}) \\
(.021)(.159)
\end{array} & .60 \\
(1960-73)-(1974-84) \Delta(\mathrm{I} / \mathrm{Y}) & =\begin{array}{l}
.025 *+.394 * *(\mathrm{NS} / \mathrm{Y}) \\
(.011)(.087)
\end{array} & .62
\end{array}
$$

Combined Market and

official Borrowers

( 34 observations)

$$
\begin{aligned}
& 1960-73 \quad(\mathrm{I} / \mathrm{Y})=\frac{.131 * *+.002 \mathrm{DO}}{(.034)(.042)} \\
& +\underset{(.165)}{.445 *(\mathrm{NS} / \mathrm{Y})}-\underset{(.095 \mathrm{DO})}{.065)}(\mathrm{NS} / \mathrm{Y}) \quad .31 \\
& \begin{aligned}
& 1974-84 \quad(I / Y)= .049 \\
&(.027)+.066 * D 0 \\
&(.039)
\end{aligned} \\
& +.878 * *(\mathrm{NS} / \mathrm{Y})-.192 \mathrm{DO} \cdot(\mathrm{NS} / \mathrm{Y}) \quad .74 \\
& (.108) \quad(.234) \\
& (1960-73)-(1974-84) \Delta(I / Y)=\underset{(.007)}{.011}+\underset{(.011)}{.014 D 0} \\
& +\underset{(.097)}{.656 * * \Delta(\mathrm{NS} / \mathrm{Y})}-\frac{.262 * \mathrm{DO} 0 . \Delta(\mathrm{NS} / \mathrm{Y})}{(.117)} .73
\end{aligned}
$$

Instrumental Variables Regressions:

Military Expenditures/GNP

and the Dependency Ratio

Official Borrowers

(13 observations)

$1960-73$

$$
(I / Y)=\frac{.217}{(.113)}-\frac{.140(\mathrm{NS} / \mathrm{Y})}{(.645)}
$$


Table 5 (concluded). Regressions of I/Y Against NS/Y:

Market Borrowers Versus Official Borrowers $1 /$

Country Group

(and number of observations )

Sample Period Regression Equation

Adjusted $R^{2}$

$$
\begin{aligned}
1974-84 & (\mathrm{I} / \mathrm{Y})=\underset{ }{.131 * *+}(.549(\mathrm{NS} / \mathrm{Y}) \\
(.034) & (.265) \\
(1960-73)-(1974-84) \Delta(\mathrm{I} / \mathrm{Y})= & .028+\begin{array}{l}
.456 * \Delta(\mathrm{NS} / \mathrm{Y}) \\
(.014)
\end{array}
\end{aligned}
$$

Market Borrowers

(21 observations)

$$
\begin{aligned}
& \text { 1960-73 } \\
& (I / Y)=\frac{.058}{(.091)}+\frac{.819(\mathrm{NS} / \mathrm{Y})}{(.461)} \\
& \text { 1974-84 } \\
& (I / Y)=\frac{-.113}{(.138)}+\frac{1.56 *(\mathrm{NS} / \mathrm{Y})}{(.576)} \\
& (1960-73)-(1974-84) \\
& \Delta(I / Y)=\underset{(.020)}{.008}+\frac{.738 \Delta(N S / Y)}{(.467)}
\end{aligned}
$$

Combined Market and

Official Borrowers

( 34 observations)

$$
\begin{aligned}
& \text { 1960-73 } \\
& (I / Y)=\frac{.058}{(.114)}+\frac{.159 D 0}{(.144)} \\
& +\underset{(.581)}{.819(\mathrm{NS} / \mathrm{Y})}-\frac{.960 \mathrm{DO} .(\mathrm{NS} / \mathrm{Y})}{(.769)} \\
& \text { 1974-84 } \\
& (I / Y)=\frac{-.113}{(.115)}+\frac{.245 D 0}{(.133)} \\
& +1.56 * *(\mathrm{NS} / \mathrm{Y})-1.012 \mathrm{DO} \cdot(\mathrm{NS} / \mathrm{Y}) \\
& \text { (.483) (.705) } \\
& (1960-73)-(1974-84) \Delta(I / Y)=\underset{(.027)}{.008}+\underset{(.029)}{.020 D O} \\
& +\underset{(.616)}{.738 \Delta(\mathrm{NS} / \mathrm{Y})}-\underset{(.633)}{.283 D O \Delta(\mathrm{NS} / \mathrm{Y})}
\end{aligned}
$$

\footnotetext{
* Significant at 95 percent level.

** Significant at 99 percent level.

1/ Standard errors are given in parentheses. $\Delta$ denotes the change in a given variable, and DO is a dummy variable which has the value of 1 (otherwise zero) when the country is an official borrower. See the Appendix for definitions and sources of data.
} 
IV. Country Size and the Saving-Investment Correlation

We noted at the outset three conditions, all of which taken together were sufficient if investment were to be uncorrelated with national

saving: (1) investment depends only on the national rate of return (and purely random factors); (2) the domestic real rate of return equals the world real rate of return; and (3) the world real rate of return is exogenous. It was argued that, even if condition (2) holds, condition (1) is very unlikely to hold since the gap between the domestic and world rates of return may be affected by endogenous domestic factors. The instrumental variable regressions are a way of attempting to deal with the econometric problems created by such endogeneity.

The failure of condition 3 is another possible econometric problem that has been pointed out by a number of authors. For a country large enough to affect world financial market conditions, a fall in national savings might drive up interest rates and crowd out investment everywhere in the world. It would be erroneous to conclude from the fact that domestic investment fell when domestic savings fell that there was low capital mobility, if the rise in interest rates and fall in investment were as large abroad as in the domestic country. This argument is of particular interest here because it might seem to explain our findings in Section III, that the saving investment coefficients appear to be higher for industrialized countries (which of course tend to be larger in world financial markets) than for developing countries. 
Of the Feldstein-Horioka critiques, Murphy (1984) focuses most explicitly on the failure of the world interest rate to be exogenous, $\operatorname{cov}\left(r^{*}, N S / Y\right) \neq 0$ in our equation (2). 1/ As a way of addressing the effect of country size, he divides his sample of 17 OECD countries in two, and finds that the seven large countries have a higher coefficient on saving $(0.98)$ than the ten small countries $(0.59)$. He interprets the results as supporting the claim that the high Feldstein-Horioka coefficients could be due to country size rather than to imperfect capital mobility.

The argument is very relevant in the case of time series studies. Obstfeld (1985), for example, attributes the high correlation coefficient he gets for a U.S. time series to the size of the United States in world markets. As a fix-up, Tobin (1983) proposes including, in the equation for any given country's investment, the saving rates for all the other individual countries in the sample; he argues that under the hypothesis of perfect capital mobility, a country's saving will have no more effect on its own investment than on other countries' investment. $2 /$ This technique would use up too many degrees of freedom. But a natural solution is to include the saving rates of the rest of the world aggregated. Frankel (1985) converts the U.S. saving rate to deviations from the world saving rate, converts the U.S. investment rate to deviations from the world

1/ Harberger (1980), Tobin (1983), and Obstfeld (1985) also criticized Feldstein and Horioka on the grounds of the "large country" problem.

2/ Tobin acknowledges that the solution is relevant only for time series studies, not cross-section, but he seems to believe that the problem itself is relevant and serious even in cross-section studies. 
investment rate, and finds that the two variables remain highly correlated. The argument is that if capital were perfectly mobile, and crowding out of investment were due only to the large size of the United States in world capital markets, then there should be no effect of saving on the U.S. Investment rate beyond the effect on the rest of the world's investment rate. The rejection of this hypothesis suggests that the savinginvestment correlation cannot be attributed to the large country effect.

In cross section studies, the endogenous foreign interest rate $r$ * is not a problem to begin with. The statement, "a country's saving rate affects $r^{*}, "$ is a statement about alternative states of the world, as in time series. It is not possible that cross-section effects on the saving rate can be attributed to $\mathrm{r}^{*}$, for the simple reason that all countries share the same $r^{*}$. In equation $(2), \operatorname{cov}\left(r^{*}, N S / Y\right)$ is necessarily zero when $r^{*}$ is the same for every observation.

If one expressed national rates of saving and investment as deviations from world levels as in the time series regression, it would only change the constant term in the cross-section regression. To take the concrete example of the fall in the U.S. national savings rate in the 1980s, the large-country effect alone could in theory explain high real interest rates and a depressing effect on U.S. investment. But if real interest rates were equalized, the large-country effect alone could not explain a combination of low saving and investment rates in the United States together with simultaneous high saving and investment rates in Japan. 
Harberger (1983) offers an argument why the Feldstein results are spurious that relies on the factor of country size, but in a way unrelated to the endogeneity of the world interest rate. The argument is that large countries tend to be more diverse than small countries (more like U.S. states and less like city blocks, in Harberger's words). For this reason, multiple saving and investment shocks tend to cancel out, and there is proportionately less of a need for the country in the aggregate to borrow or lend to the rest of the world. When there is a drought in a small country, it affects the whole economy; the country has to borrow from abroad. But when there is a drought in Kansas, there may be a good harvest in California, or a high-tech boom in Massachusetts, or an oil discovery in Alaska, so that there is proportionately less need for the United States to borrow from abroad. The argument is analogous to the optimum currency area literature of the early 1960 s which relied on the regularity that the larger and more economically diverse a region was, the less need did it have (proportionately) for trade in labor or goods. with other regions. $1 /$

Harberger (1983) specifically addresses the issue of industrialized versus developing countries:

The point to be borne in mind here is that the evidence of the Feldstein-Horioka paper was assembled from the OECD countries only. Casting the net wider would have surely thrown up indications of much greater divergence between saving and investment rates (p. 334). Harberger's point is a convincing explanation of why current account/ GNP ratios such as calculated by him, Feldstein and Horioka (1980), 
Feldstein (1983), Sachs (1981, pp. 233-37), and Penati and Dooley (1984), Caprio and Howard (1984), and Summers (1985), might be closer to zero for large countries than for small countries. But it does not seem in itself to explain why the investment-saving regression coefficient would be higher for large countries than for small countries. If the variance of the saving rate $\mathrm{S} / \mathrm{Y}$ (or of the investment rate disturbances) is smaller for large countries because shocks cancel out, but changes in net capital inflow per unit change in the current account are the same, then the variance of the current account will also be smaller but the regression coefficient need not be.

Let

(4) $I / Y=\alpha+\beta(N S / Y)+\varepsilon$

Here, $\beta$ depends on parameters, such as the degree of capital mobility and the sensitivity of investment to the interest rate, which we will assume the same for different countries. Then,

(5) $\mathrm{CA} / \mathrm{Y}=\mathrm{NS} / \mathrm{Y}-\mathrm{I} / \mathrm{Y}=-\alpha+(1-\beta) \mathrm{NS} / \mathrm{Y}-\varepsilon$,

and $\operatorname{Var}(\mathrm{CA} / \mathrm{Y})=(1-\beta)^{2} \operatorname{Var}(\mathrm{NS} / \mathrm{Y})+\operatorname{Var}(\varepsilon)+2(1-\beta) \operatorname{Covar}(N S / Y, \varepsilon)$. The last term is zero in large samples, in the event (extremely unlikely without the use of instrumental variables, as we saw in Section III) that the error term is well behaved. If $\operatorname{Var}(S / Y)$ and $\operatorname{Var}(\varepsilon)$ are smaller for large countries, then $\operatorname{Var}(\mathrm{CA} / \mathrm{Y})$ will be smaller as well, as Harberger claims. Nevertheless, a regression coefficient will be estimated as

(6) $B \equiv \frac{\operatorname{Cov}(I / Y, S / Y)}{\operatorname{Var}(S / Y)}=\beta+\frac{\operatorname{Cov}(S / Y, \varepsilon)}{\operatorname{Var}(S / Y)}$ 
where again the last term is zero in large samples in the event that the error term is well behaved. The important point is that we should expect $B$ to be no higher among large countries than among small countries. $1 /$ Murphy (1984) pursues Harberger's suggestion that one should find more apparent capital mobility for smaller units than for large. He regresses the investment rate against the saving rate for a cross section of 143 U.S. corporations and finds a significant coefficient. He argues that since the corporate capital market is "by almost all standards, a well integrated capital market with a high degree of capital mobility," (p. 335), the correlation test must not be correct. But there is an element of circularity to this argument. On the one hand, the proposed explanation for the spurious Feldstein-Horioka results, an endogenous market-wide interest rate, is not relevant for the cross-section of corporations. On the other hand, there are perfectly good theoretical and empirical reasons for thinking that corporations' liabilities are not, in fact, perfect substitutes for each other in investors' portfolios and that corporations cannot borrow unlimited amounts at the going interest rate. We are left doubting the perfect integration of the corporate capital market more than the reliability of the test.

\section{Financial and Real Capital Mobility}

In our view the evidence that levels and changes in national savings and investment ratios move together stands up to the empirical issues

1/ The standard error of $\beta$ in small samples could be affected one way or the other. 
raised in the previous sections. In terms of the three conditions laid out at the beginning of this paper, it is the failure of the second condition, $r=r^{*}$, that remains the most likely explanation for the position covariance of national savings and investment. One reason why many observers continue to resist the implications of this evidence is that it seems so clearly at odds with the apparent integration of financial capital markets, especially those of developed countries. If by capital mobility we mean the tendency for investors to equalize expected rates of return on a subset of liquid, short-term, default-free, financial assets denominated in different currencies or issued by residents of different countries, then there can be little doubt that capital is mobile among the major industrial countries. 1/ This definition of capital mobility, however, is of limited value. It is analogous to measuring the degree of integration of international goods markets by noting that prices (measured in a common currency) are equalized for a subset of goods. There certainly are a large number of agricultural and

\footnotetext{
1/ However it should be noted that, even if capital is sufficiently mobile to equalize internationally expected rates of return on two assets, the equalization will take place in terms of any common currency or other numeraire, not in terms of the countries' respective goods. Thus, real interest par $\overline{i t y}$, which is the condition relevant for saving and investment, need not hold unless we have not only uncovered interest parity, but also purchasing power parity. See Frankel (1985) for an elaboration of this point.
} 
mineral commodities for which this condition holds quite strictly. It is clear, however, that this condition tells us nothing about the tendency of prices of goods in general to be equalized across countries. In fact, this more interesting purchasing power parity measure of "goods mobility" has failed to hold in recent years. The key to this more general condition is that within countries the relative prices of goods change by substantial amounts and with no apparent tendency to return to their original levels.

An analogous argument can be made in the context of international markets for securities. The fact that a subset of financial instruments issued by residents of different countries appear to be perfect substitutes does not mean that the financial markets are fully integrated. As is also true for goods markets, a useful measure of "capital mobility" would require that "traded" and "nontraded" financial assets be perfect substitutes in residents' portfolios so that the relative yields on these assets within countries are largely independent of international influences.

The existence of "nontraded" securities is, of course, not obvious. It can be argued, however, that the possibility of ex post taxation of some types of international positions acts as a barrier to trade in such assets. Moreover, it is possible that the net indebtedness of a country is an important determinant in its incentive to impose such taxes.

The idea that net claims on a given country might be important to wealth holders is difficult to model. There is no aggregate asset called "net claims" that we can identify nor can we directly measure the yield 
necessary in order to induce wealth holders to hold this net position. In most cases net claims on a given country are a small difference between two large numbers, gross claims and gross liabilities. Thus while it may be clear that a risk exists when a country's net debt to the rest of the world grows it is not clear who holds that risk, that is, how a loss would be allocated among holders of various financial claims on the country.

The government, for example, may perceive different costs in damaging the reputation of various forms of investments. Its own securities might be an example of an asset unlikely to be taxed, particularly if these are held by foreign governments. Equity claims, however, might be relatively easy to identify as owned by nonresidents and, because they impart control of domestic firms, constitute a relatively attractive tax base for political reasons.

If assets such as Treasury securities and equity claims are imperfect substitutes within countries the structure of yields between countries and within countries will reflect a complex set of expectations concerning the likely incidence of an ex post tax on nonresident claims as well as "arbitrage" conditions that will determine how and by whom such risks are borne.

It follows that arbitrage among a select set of internationally traded "safe" financial assets need not imply that yields on more vulnerable nontraded assets are also equalized. What is necessary is that differentials that might arise within a country are not closely arbitraged. That is, the yields on Treasury securities and other 
tradable securities would have to diverge from yields on equities and other nontradable assets. The analogy in goods markets would be that prices of traded goods are equalized across countries but the relative prices of traded and nontraded goods within countries will change in response to economic conditions.

This framework might be made more clear by illustrating the financial and real linkages between and within two very simple economies. Financial assets consist of claims on physical capital, E, interest-bearing claims on the government, $B$, and fiat money, $M$. The yield on equity claims is the marginal revenue product of the capital stock, $r_{p}$. Interest-bearing government bonds yield a nominal rate of $r_{p}$ and $f i a t$ money, which is also a liability of the governments, yields no nominal return.

(1) $M^{d}=M^{d}\left(\bar{r}_{p}, \bar{r}_{g}\right)$

(2) $B^{d}=B^{d}\left(\bar{r}_{p}, \stackrel{+}{r}_{g}\right)$

(3) $E^{d}=E^{d}\left(\stackrel{+}{r}_{p}, \bar{r}_{g}\right)$

In describing the linkages between the two countries' financial systems it is assumed that government bonds are traded securities while equity claims are nontraded securities. As with goods and services the terms traded and nontraded securities are an analytical convenience that represents a continuum of assets. For simplicity it is assumed that government-issued securities are perfect substitutes across countries so that

(4) $r_{g}=r_{g}^{*}+E(\dot{e})$ 
However, since equity claims are not traded, the linkages between $r_{p}$ and $r_{p}$ * are only indirect. The two monies are tradable but are assumed to be dominated by government securities in the portfolios of nonresidents. 1/ These financial market assumptions are illustrated as follows:

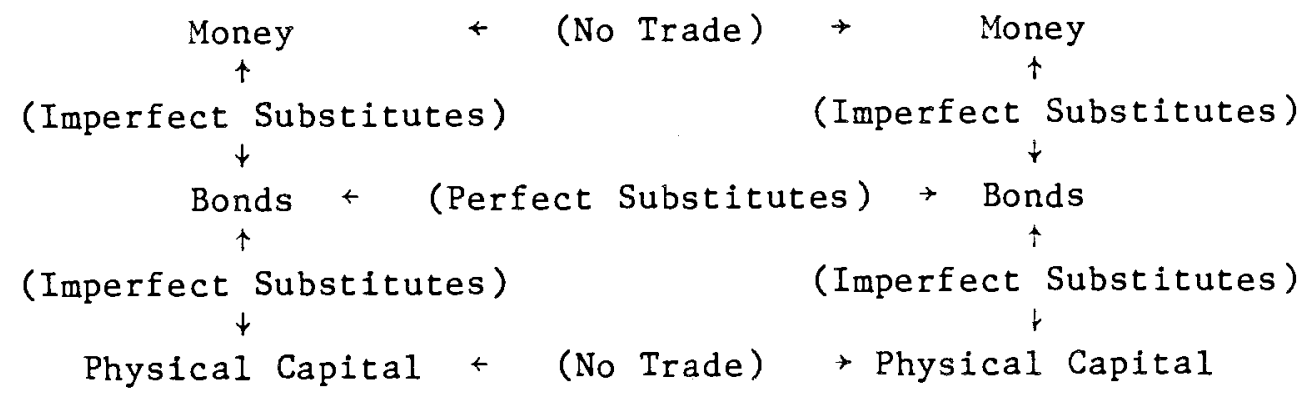

Note that the arbitrage between the two capital stocks is limited both across, due to country risk, and up and down, due in our assumptions concerning substitution parameters between equities and government bonds. The linkages between the financial sector and real sector within each country are as follows. Real investment is defined as transforming current output into a capital good which has an "own" rate of return in terms of future output. Investment will be positive when the present value of the expected future output exceeds the cost of the capital. As discussed above, the discount rate, $r_{p}$, need not be equal to the government security rate since domestic savers might require a variable differential in order to hold willingly existing government debt and claims on the capital stock.

1/ In terms of the literature we are thus assuming "perfect capital mobility" but no currency substitution. Note however, that the addition of nontraded securities to the model will alter the "standard" interpretation of "capital mobility" as defined by (4). 
(5) $I=I\left(r_{p}\right)$

Savings in each country is a function of two independent rates of return, the two government bond yields (which are assumed equal because of arbitrage across countries) and the yield on the domestic capital stock.

(6) $S=S\left(r_{p}, r_{g}\right)$

The real sector linkages between countries are derived from the above conditions and the balance of payments constraint. That is, a net excess demand for the traded security must be identically equal to the differences between output and absorption (or public plus private savings and investment) in each country. The mechanism that insures this equality is left in the background. It may or may not involve income, prices and real exchange rate changes, which are assumed unchanged in this discussion.

The essential features of this framework are illustrated below (Figure 1). Because these relations are drawn with respect to returns on traded securities, the yield on nontraded securities, $r_{p}$, is a parameter in the savings and investment functions. Since government bonds are perfect substitutes across countries, $r_{g}$ and $r_{g}$ are always equal. In the initial position, domestic savings for both countries are set equal to domestic investment plus the domestic fiscal deficit at $r_{g}^{o}$ by assumption.

It is evident that shifts in the $I, I *$ or $S$, $S *$ functions, or a change in either countries' fiscal deficit, will result in some net trade of government bonds and a current account imbalance in this framework. 
Figure 1

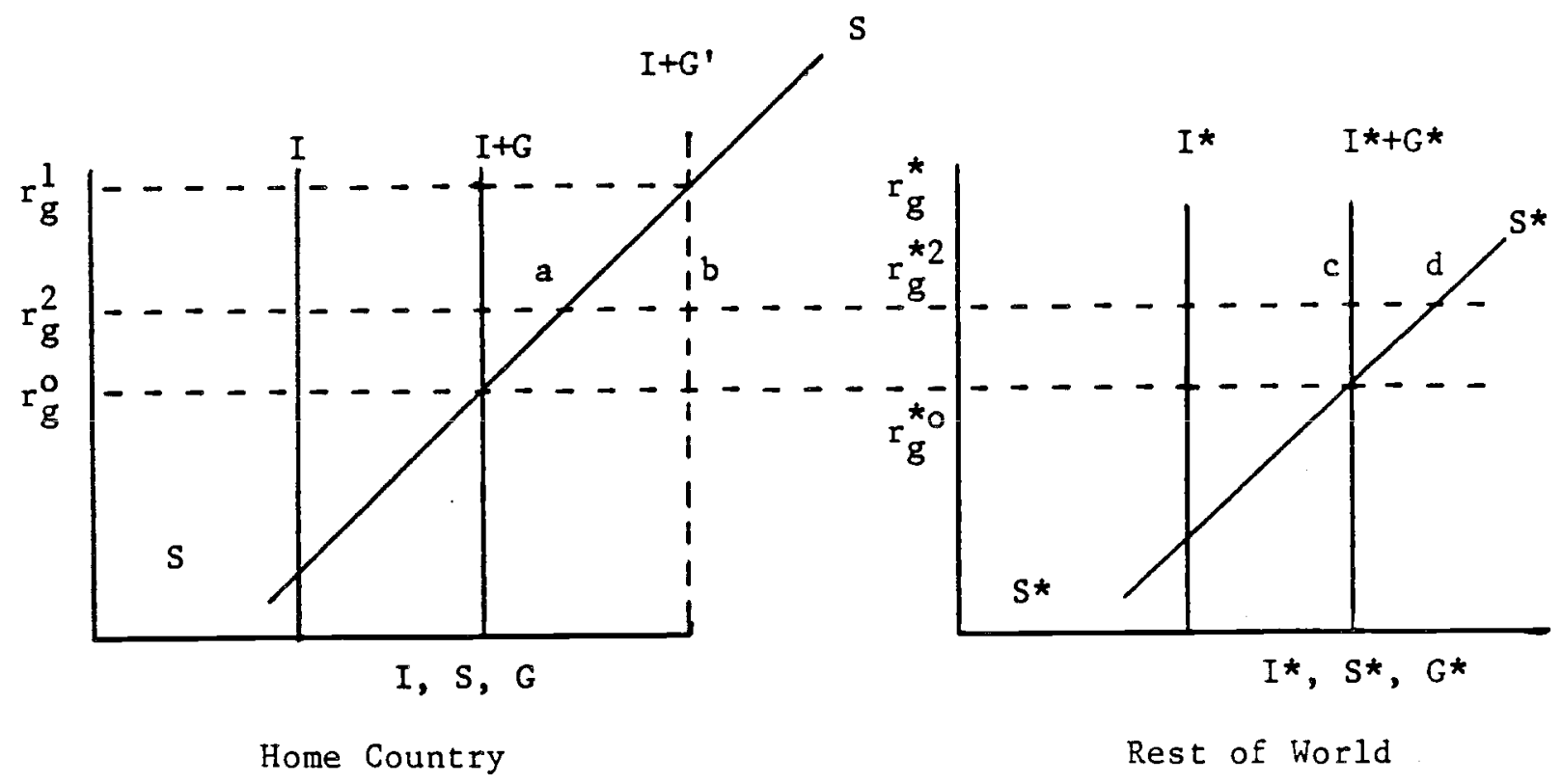

But there is no presumption that this trade in "safe" securities will be sufficient to equalize $r_{p}$ and $r_{p}^{*}$. In general the disturbance in this model will be dissipated by both a change in the structure of yields, savings and investment behavior within countries, and net trades of goods and securities between countries. The relative importance of these equilibrating mechanisms depends on the degree of segmentation of financial markets, the response of savings and investment to the two financial yields, and the nature of the shock to the system.

Suppose in this system the domestic fiscal deficit increases (due to a bond financed increase in government expenditures), shifting the $I+G$ curve to the right to $I+G^{\prime}$ (Figure 1 ). In autarky $r_{g}$ would be bid $u$, and if $r_{p}$ was bid up only slightly, so that shifts in I and $S$ were negligible, $r_{g}^{0}$ would rise to $r_{g}^{1}$. If we now open the economy, and assume that $r_{p}^{*}$ is about unchanged, $r_{g}^{*}$ will also be bid up and the new 
equilibrium will be at $r_{g}^{2}=r_{g}^{* 2}$. At this point the traded security yields will have risen sufficiently to increase $S+S^{*}$ so that the domestic fiscal deficit is covered. This will generate a current account deficit in the home country, a b, equal to the difference between domestic savings and $I+G^{\prime}$, and a current account surplus, $c d$, in the foreign country. There is an equivalent net trade of government securities. If we assume that the financial markets are highly integrated within each country, a rise in $r_{g}=r_{g}^{*}$ will tend also to raise $r_{p}$ and $r_{p}^{*}$. In this case the $S$ and $S^{*}$ curves in Figure 1 would shift to the right and the $I+G^{\prime}$ and $I^{*}+G^{*}$ curves would shift to the left as private investment is crowded out. If the two countries were identical, the rise in $r_{g}=r_{g}{ }^{*}$ would be less but we would observe the same current account deficit following a fiscal deficit as described above.

A shift in the investment schedule or the saving schedule would differ in at least one important respect from the fiscal deficit shock discussed above. Assume that the private investment function shifts to the right by the same amount as the fiscal deficit discussed above so that $I+G$ shifts to $I^{\prime}+G$ (Figure 2$)$. The effects of such a shift appear to be similar as described above in that $r_{g}^{0}=r_{g}^{*_{0}}$ would rise until the level of savings in both countries covered the increase in investment at $r_{g}^{1}, r_{g}^{* 1}$. 
Figure 2

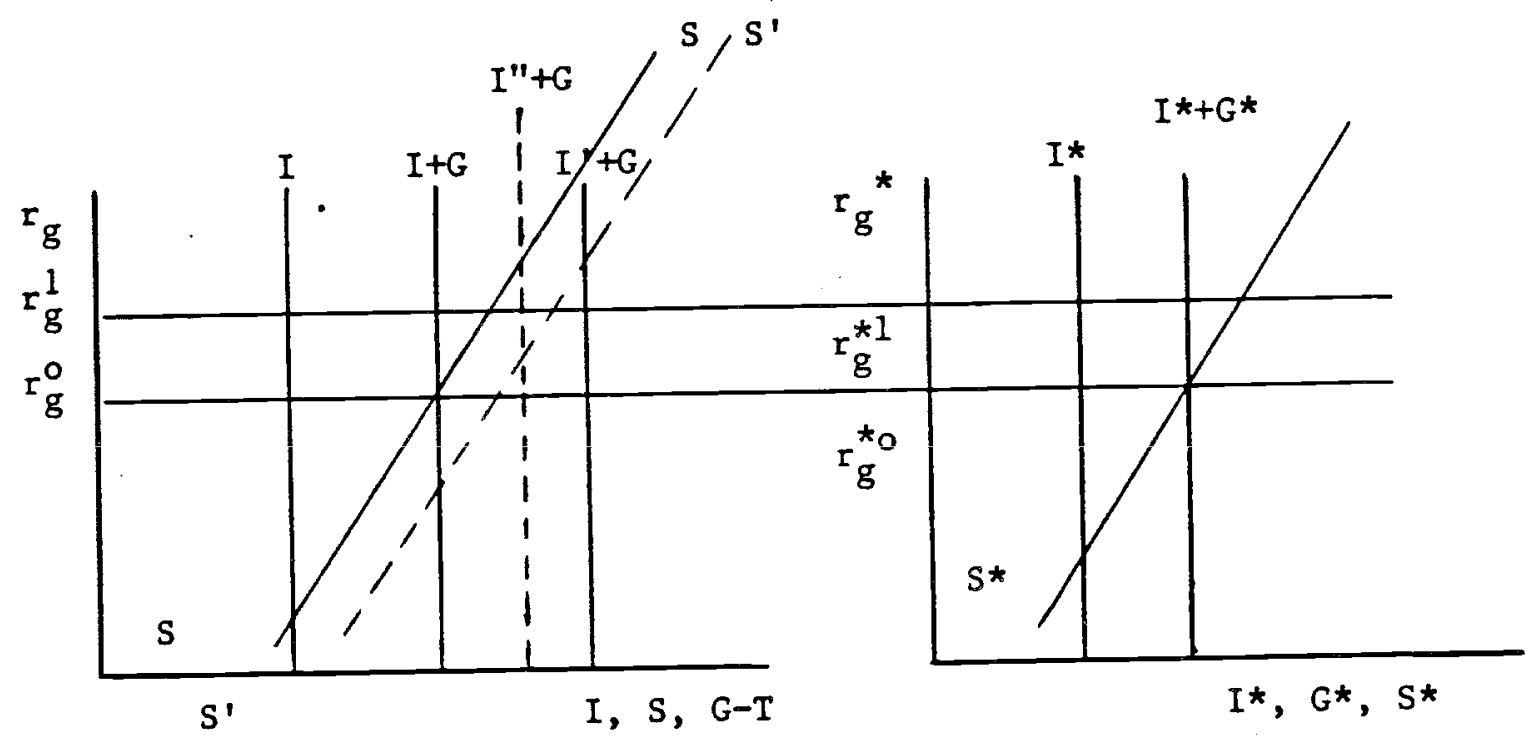

However, in this case the shift in the domestic investment function would tend to raise $r_{p}$ directly and this would shift $I^{\prime}+G$ to $I^{\prime \prime}+G$. Moreover, the rise in $r_{p}$ would cause $S S$ in Figure 2 to shift to the right to S' S'. For these reasons an ex ante shift in the domestic investment schedule would have a smaller effect on the traded securities market shown as shown by the dashed curves in Figure 2. The initial disequilibrium in the domestic traded securities market would be mitigated by a rise in $r_{p}$. It follows that the size of the shock transmitted to the other country is smaller as compared to a fiscal deficit if the domestic financial market is poorly integrated. For this reason the current account imbalance would also be smaller.

In general, it apears that a more complete description of the linkages among financial markets within and between countries might help to explain the correlations between domestic savings and domestic 
investment. The very simple model proposed above suggests that these correlations should break down in cases where the dominant shocks to the system are unusually large fiscal deficits that are uncorrelated across countries. In the absence of such conditions, differences or changes in domestic savings and investment functions might have limited impact on current account imbalances.

\section{Concluding Remarks}

The evidence brought together in this paper suggests to the authors that a close association between national savings and national investment is a robust empirical regularity. This finding casts considerable doubt on the widely held view that national markets for physical capital are highly integrated. The positive correlations between levels and changes in national saving rates and investment rates, which are apparent both for industrial countries and developing countries and which are higher in recent years as compared to earlier time periods, stand up to a variety of econometric objections. The only data set for which the empirical regularity is not apparent includes developing countries that depend primarily on aid to finance current account imbalances.

The fact that national markets for some types of financial capital are integrated may be irrelevant in evaluating the degree of integration of national markets for physical capital. The tendency for expected returns on liquid, default free financial assets to be equalized does not imply that expected returns on physical capital are also equalized. 
We do not know why the apparent isolation of national markets for physical capital has persisted in the face of substantial expansion of trade in goods and services and financial capital. Further research into these matters might focus on the impediments to net transfers of real savings to "foreign" political jurisdictions. A better understanding of such factors might suggest policy measures that would encourage more productive use of world savings. 


\section{Data Sources}

GDP at market prices, (Y) gross domestic investment, (I) and gross domestic savings (NS) are conventional national income concepts drawn from World Bank EPDNA data files. The age dependency ratio is the ratio of dependent population (under 16 and over 64) to working age population (15 to 64) drawn from the same source. Military expenditures are from data files of the U.S. Arms Control and Disarmament Agency. The definitions for official borrowers, market borrowers and combined borrowers as well as lists of countries in each category can be found on pages 173-174 of the International Monetary Fund's 1986 World Economic Out look. 


\section{References}

Caprio, Gerard and David Howard, "Domestic Saving, Current Accounts, and International Capital Mobility," International Finance Viscussion Papers No. 244. Federal Reserve Board, Washington, D.C. (June 1984).

Cumby, Robert and Frederick Mishkin, "The International Linkage of Keal Interest Rates: The European-U.S. Connection." NBER Working Paper No. $1423,1984$.

Feldstein, Martin, "Domestic Saving and International Capital Movements in the Long Run and the Short Run," European Economic keview 21 , (1983), pp. 129-151.

Feldstein, Martin and Charles Horioka, "Domestic Saving and International Capital Flows," Economic Journal 90, (1980), pp. 314-329.

Fieleke, Norman, "National Saving and International Investment," In Saving and Government Policy, Conference series no. 25, Boston: Federal Bank of Boston (1982).

Frankel, A. Jeffrey, "International Capital Mobility and Crowding Out in the U.S. Economy: Imperfect Integration of Financial Markets or of Goods Markets?" NBER Working Paper No. 1773, 1985. In How Open is the U.S. Economy?, R. Hafer, ed. (Lexington Books, Lexington), 1986.

Harberger, Armold, "Vignettes on the World Capital Market," American Economic Review 70, (1980), pp. 331-337.

Hurphy, Robert, "Capital Mobility and the Relationship Between Saving and Investment in OECD Countries," Journal of International Money and Finance, Vol. 3, (1984), Pp. 327-342.

Obstfeld, Maurice, "Capital Mobility in the World Economy: Theory and Measurement," Carnegie-Rochester Public Policy Conference (1985).

Penati, Alessandro and Michael Dooley, "Current Account Imbalances and Capital Formation in Industrial Countries, 1949-1981" IMF Staff Papers, Vol. 31, (1984), pp. 1-24.

Sachs, Jeffrey, "The Current Account and Macroeconomic Adjustment in the 1970s," Brookings Papers on Economic Activity, Vol. 12, (1981), pp. $201-268$.

"Aspects of the Current Account Behavior of OECD Economies," in E. Claassen and P. Salin, eds., Recent Issues in the Theory of Flexible Exchange Rates, Amsterdam: North-Holland (1983). 
Summers, Lawrence, "Tax Policy and International Competitiveness," NBER Working Paper (March 1985). In International Aspects of Fiscal Policies, Jacob Frenkel, ed. (Univ. of Chicago Pressi Chicago), forthcoming.

Tobin, James, "Comments on Domestic Saving and International Capital Movements in the Long Run and the Short Run," European Economic
Review, Vol. 21, (1983), pp. 153-156.

Westphal, Uwe, "Comments on Domestic Saving and International Capital Movements in the Long Run and the Short Run," European Economic Review, Vo1. 21, (1983), pp. 157-159. 